1

2

3

\title{
Reservoir Sedimentation and Upstream Sediment Sources: Perspectives and Future Research Needs on Streambank and Gully Erosion
}

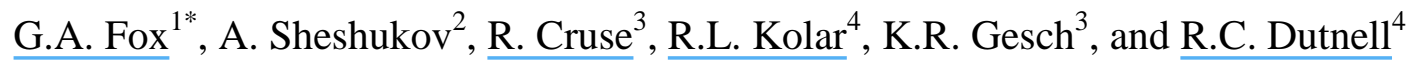 \\ ${ }^{1}$ Professor and Buchanan Endowed Chair and Interim Director of the Oklahoma Water \\ Resources Center, Oklahoma State University, 120 Agricultural Hall, Stillwater, OK 74078 \\ ${ }^{2}$ Assistant Professor, Biological and Agricultural Engineering, Kansas State University, \\ Seaton Hall 048, Manhattan, KS 66506 \\ ${ }^{3}$ Professor and Director of the Iowa Water Center and Ph.D. Student, respectively, \\ Department of Agronomy, 3212 Agronomy Hall, Iowa State University, Ames, IA 50011- \\ 1010 \\ ${ }^{4}$ Professor and David Ross Boyd and Austin Presidential Professor and Ph.D. Student, \\ respectively, Department of Civil and Environmental Engineering, University of Oklahoma, \\ Norman, OK 73019
}

\footnotetext{
* Corresponding Author: Oklahoma State University, 120 Agricultural Hall, Stillwater, OK
} 74078; E-mail: garey.fox @ okstate.edu; Phone: 405-744-5616; Fax: 405-744-6059 


\title{
Reservoir Sedimentation and Upstream Sediment Sources: Perspectives and Future Research Needs on Streambank and Gully Erosion
}

\begin{abstract}
The future reliance on water supply and flood control reservoirs across the globe will continue to expand, especially under a variable climate. Construction of additional reservoirs is less likely compared to simultaneous flow and sediment management in existing reservoirs. One aspect of this sediment management is related to the control of upstream sediment sources. However, key research questions remain regarding upstream sediment loading rates. Highlighted in this article are research needs relative to measuring sediment transport rates and loading due to streambank and gully erosion within a watershed. For example, additional in-stream sediment transport and reservoir sedimentation rate measurements are needed across a range of watershed conditions, reservoir sizes, and geographical locations. More research is needed to understand the intricate linkage between upland practices and in-stream response. A need still exists to clarify the benefit of restoration or stabilization of a small-reach within a channel system or maturing gully on total watershed sediment load. We need a better understanding of the intricate interactions between hydrological and erosion processes to improve prediction, location, and timing of streambank erosion and failure and gully formation. Also, improved process-based measurement and prediction techniques are needed that balance data requirements regarding cohesive soil erodibility and stability as compared to simpler topographic indices for gullies or stream classification systems. Such techniques will allow the research community to address the benefit of various conservation and/or stabilization practices at targeted locations within watersheds.
\end{abstract}

Keywords: Cohesive sediment transport; Gully erosion; Reservoir sedimentation; Streambank erosion 


\section{Introduction}

According to Morris and Fan (2010), there are 42,000 large (over $15 \mathrm{~m}$ tall) dams worldwide and the number of dams increases substantially when you include smaller size reservoirs. In fact, the National Inventory of Dams (NID) reports that there are approximately two million dams in the United States with less than $61,700 \mathrm{~m}^{3}$ (50 acre-ft) capacity. The impact of these dams on economic development, especially in rural areas, is considerable. The USDA Small Watershed Program, for example, has constructed over 11,000 flood control dams nationwide in 47 states (Hanson et al. 2007). In Oklahoma alone, more than 2,000 flood control dams have been constructed in 121 watersheds. These dams provide flood protection for more than two million acres with an estimated infrastructure investment of approximately $\$ 2$ billion. The price tag for updating this infrastructure is already enormous; estimates are close to $\$ 53$ million in Oklahoma alone, and as sedimentation continues to occur in these reservoirs the cost will only continue to grow. Furthermore, with continued population and economic growth and development coupled with increasing climate variability, future reliance on water supplies and flood control provided by reservoirs will increase significantly (Hargrove et al. 2010).

Small and large dams impact streams both upstream and downstream of the impoundment. Streams typically evolve towards a dynamic equilibrium in which the sediment supply coming into a particular reach tends towards equilibrating with the sediment supply leaving the reach (ASCE 2008). Construction of the dam impounds the river reach, causing flow velocities to decrease significantly entering the impoundment, resulting in the deposition of the sediment that was being carried from upstream as bed load, suspended load, and wash load. Verstraeten et al. (2003) referenced WCD (2000) in that the annual rate of loss in the storage 
capacity of the world's reservoirs was approximately 0.5 to $1.0 \%$. Theoretically, streams adjust to the impoundment, depositing sediment in the reservoir, which correspondingly reduces the storage capacity and potential flood protection. This loss in storage capacity due to the sediment deposition means less flood retention and protection, and it can impact hydropower production, navigation, recreation, and the ecosystem. In terms of hydropower, excessive sediment can block intakes and accelerate the abrasion of hydraulic machinery. Localized deposits in delta areas can create localized flooding, navigation issues, and alter the ecological system (Morris and Fan 2010).

Issues associated with sediment transport, aquatic habitat, and infrastructure damage can occur downstream of the reservoir. The impoundment drastically alters the hydraulic flow regime, potentially resulting in less frequent, high magnitude events that can alter the ecological balance in rivers and streams. When the sediment supply is removed by the impoundment, the release of "hungry" water can lead to streambed degradation, streambank erosion and failure, and increased scour at structures such as bridges. In some cases, the altered sediment transport from the streambed downstream of the reservoir results in armoring of the streambed, negatively impacting aquatic habitat.

Morris and Fan (2010) call explicitly for sustainable reservoir operation and management that considers not only the flow but also the sediment transported into and out of the reservoir. The design strategy for many reservoirs and flood control structures has historically been to build the impoundment large enough for an estimated design life with the assumption that sedimentation will eventually occur. They note the need to replace the concept of a limited design life with dual management of flow and sediment for “...preservation and continued 
utilization of existing reservoir sites, not the continued exploitation of a shrinking inventory of potential new sites".

Podolak and Doyle (2015) give a succinct analogy when it comes to the issues associated with reservoir sedimentation: “...there is a persistent chronic loss of the very resource upon which many aspects of society depends. Any diminishing resource for which there is increasing demand merits being regularly measured, assessed and efficiently managed relative to society's expectations and dependence." In their recent forum paper, they call specifically for the expansion of nationwide reservoir sedimentation surveys, supplement the Reservoir Sedimentation Survey Database (RESSED) with planned sedimentation rates, and share responsibility for building reservoir sedimentation knowledge. They also point out a critical problem is that many reservoirs are filling in at rates that are quite different than those projected during the design phase. Podolak and Doyle (2015) reference John Redmond Reservoir in Kansas as a case where sedimentation rates are twice as high as originally expected. In other locations, reservoir sedimentation rates are slower than originally expected. A need exists to examine why such variability occurs and as discussed below, simple empirical or statistical models are not always able to tease out the complex interactions between land use/cover, precipitation, and sediment sources.

As pointed out by numerous authors (e.g., Podolak and Doyle 2015), it is critical that we collect additional information on historical and current sedimentation rates in small and large reservoirs to understand their current status. We agree that survey data are not collected frequently enough and when performed there is a bias towards the survey of larger reservoirs. However, this forum paper emphasizes that it is also imperative to better understand sources of sediment reaching the reservoir. The historical focus on upland sources of sediment from 
agricultural fields needs to be supplemented with knowledge regarding sediment loading rates from streambanks and gullies. Therefore, an objective of this forum paper is to highlight streambanks and gullies as two unique sources of upstream sediment. The paper highlights future research needs for quantifying sediment loads from these sources so that a complete picture of upstream sediment loads may be painted.

\section{Controlling Upstream Sediment}

Upstream erosion control has largely been the focus of efforts to slow the eventual sedimentation of reservoirs for the "preservation and continued utilization of existing reservoirs" (Morris and Fan 2010). Examples of conservation practices that help to limit upland sources of sediment from entering rivers and streams include the installation of riparian buffers and vegetative filter strips, conversion of conventional tillage to conservational tillage or no-till practices, conversion of row crops to pasture, grassed waterways, and terracing (Hargrove et al. 2010). However, in some cases, the investment in conservation practices to control upland sources of sediment from rill and interrill erosion has had limited impact on sedimentation rates because past erosion is deposited in channels and floodplains and susceptible to transport. This sediment is commonly referred to as a legacy source (Trimble 2009; Hargrove et al. 2010). For example, synthesizing findings from USDA Agricultural Research Service (ARS) Conservation Effects Assessment Project (CEAP) watershed research, Tomer and Locke (2011) noted that while practices improved local water quality, problems persisted in some watersheds: "This dissociation between practice-focused and watershed-scale assessments occurred because (i) conservation practices were not targeted at critical sources/pathways of contaminants; (ii) 
sediment in streams originated more from channel and bank erosion than from soil erosion; (iii) timing lags, historical legacies, and shifting climate combined to mask effects of practice implementation; and (iv) water quality management strategies addressed single contaminants with little regard for trade-offs among contaminants."

\section{Reservoir Sedimentation Rates and Variability}

Numerous studies have reported sedimentation rates for small and large reservoirs across the globe, and others have attempted to derive correlations between sedimentation rates and variability in these rates over time relative to catchment area, land use/cover, precipitation, and sediment sources. It is not possible to summarize every study in this forum article, so instead we focus on presenting examples that showcase the complexity in correlating sedimentation rates to one or a few variables.

First consider the study by Juracek (2014) in which reservoir sedimentation rates were studied throughout Kansas. Results suggested considerable variability among reservoirs in the state. Decreases in total water storage capacity of these reservoirs ranged from less than $5 \%$ to 55\%. Juracek (2014) also suggested a statistically significant correlation between sediment yield and precipitation. In comparison, McIntyre (2007) studied land use and reservoir sedimentation in an 1189-ha agricultural watershed in central Oklahoma. Reservoir sedimentation rates declined from approximately $6000 \mathrm{Mg} / \mathrm{yr}$ to $1000 \mathrm{Mg} / \mathrm{yr}$ from 1934 to 1987 . This decrease was hypothesized to be due to reductions in cultivated cropland with roadway erosion, streambank erosion, stored channel sediment, and long-term precipitation change declared insignificant. However, Garbrecht (2007) studied a similar agricultural watershed in west-central Oklahoma. 
He found that a wetter climate led to an increase in soil erosion and sediment yield to the Fort Cobb Reservoir even though extensive conservation practices were put into place. Therefore, a variety of reasons may exist for failure of upstream soil conservation to translate into reductions in reservoir sedimentation. In fact, as a CEAP watershed, streambanks have been estimated to contribute as much as 50 to $60 \%$ of the upstream sediment load in the Fort Cobb watershed (Simon and Klimentz 2008).

As an example from Europe, Verstraeten et al. (2003) studied sedimentation rates in 60 reservoirs in Spain. They attempted to utilize regression based models to determine highly predictive variables for the measured reservoir sedimentation rates. However, catchment area explained only $17 \%$ of the variability in specific storage yield. They specifically noted the difficulty of empirical models in these watersheds because of the significant sediment load from gullies.

So why are sedimentation rates variable and not uniformly correlated with factors such as catchment area, land use/land cover, and precipitation? One of the possible explanations is related to streambanks and gullies as significant sources of sediment in some watersheds.

\section{Streambanks as Contributor to Sediment Load to Reservoirs}

Channel erosion is known to be a significant contributor to total sediment and nutrient loading (Simon and Darby 1999; Sekely et al. 2002; Evans et al. 2006; Wilson et al. 2008; Miller et al. 2014). As mentioned earlier, in many CEAP watersheds, studies report that “....sediment in streams originated more from channel and bank erosion than from soil erosion" (Tomer and 
Locke 2011). Some studies from across the United States have suggested that streambanks can contribute as much as 85 to $90 \%$ of the total watershed yield.

Incised streams undergo a cycle of bank evolution according to the channel evolution model most recently proposed by Simon and Rinaldi (2006). Stage I channels are largely in dynamic equilibrium with no bed degradation or aggradation. Due to some change in the hydrology of the system, the channel can become incised or channelized (Stage II). This could for example be due to direct channel "improvement" where stream channels are deepened and/or straightened, or it could be a result of a change in upland hydrology, such as due to increased runoff from urban development or changes in agricultural land management. It could also be due to changes in climate relative to the duration and magnitude of storm events. During Stage III, the bed is actively degrading but the banks are, for the most part, stable. Eventually, degradation of the bed continues increasing bank slope, bank stability is lost, bank erosion and collapse accelerate, and the stream adjusts laterally (Stage IV). The presence of riparian vegetation on the banks can help to slow the erosion process during Stage IV by providing additional cohesive strength to the bank and by reducing the applied shear stress reaching the bank sediment when roots are exposed. The lateral adjustment continues in Stage V, but the stage includes aggradation of the streambed especially due to increased sediment loads from upstream reaches. Eventually, in the absence of additional disturbances or changes in the watershed hydrology, the channel will evolve to a stable channel in Stage VI with a dual floodplain (Simon and Rinaldi 2006). In fact, many restoration designs are currently built along the idea of dual floodplain design to mimic Stage VI in the channel evolution model (Lovern and Fox 2012).

To fully understand the significance of this process, consider Wildhorse Creek, near Hoover, in Garvin County, Oklahoma. Between 1922 and 1933 the channel was "improved" by 
constructing a straight $3 \mathrm{~m}(10 \mathrm{ft})$ deep trapezoidal channel with a top width of $7.6 \mathrm{~m}(25 \mathrm{ft})$ and 2:1 side slopes, as may be seen in Figure 1a (Barclay, 1980). In 1999, Dutnell (2000) found the channel to be $58.8 \mathrm{~m}(193 \mathrm{ft})$ wide and approximately $7.6 \mathrm{~m}(25 \mathrm{ft})$ deep. The channel has thus incised approximately $4.6 \mathrm{~m}(15 \mathrm{ft})$ and experienced a 20-fold increase in area (Figure $1 \mathrm{~b})$. As a result, the sediment load that finds its way to Lake Texoma, since the "channel improvements" were completed, exceeds 38 million $\mathrm{m}^{3}$. Wildhorse Creek appeared to be at Stage V, the aggradation and widening phase, in 1999, as there was evidence of deposition on inside bends and point bars were beginning to form.

So, how do streambanks erode and fail during these intermediate stages of the channel evolution model? Streambank erosion and failure is a cyclical process that includes subaerial processes (soil moisture, wetting/drying cycles, seepage, freeze-thaw cycles, and others), fluvial erosion, and mass wasting. Subaerial processes largely act to prime the banks for erosion and failure. For example, seepage can increase the erodibility of the material, making it easier for fluvial erosion to detach particles or aggregates (Fox and Wilson 2010; Midgley et al. 2013). Fluvial erosion acts in many cases to undercut the bank at the bank toe due to the higher applied shear stress during flow events at that position. Then, mass wasting occurs when the bank becomes geotechnically unstable. Of course, fluvial erosion and bed incision can lead to banks that become steeper and therefore more unstable. In many incised streams, all three of these processes are critical for sediment loading to occur, especially in streams consisting of cohesive soil layers. For example on the Barren Fork Creek in eastern Oklahoma, a composite streambank with a gravel toe and cohesive silt loam topsoil layer, process-based modeling and observations of the failure process by Midgley et al. (2012) and Daly et al. (2015) indicate that the most extreme erosive events occur when the banks are primed for failure because of high soil water 
content in the bank. High flows that occur as isolated events may transport a considerable bed load or suspended load component in the stream, but may result in limited bank retreat. Flow events with smaller return periods but that occur in sequence with other storms where soil moisture is high in the bank cause extreme erosion to occur. On the Barren Fork Creek, such a sequence of approximately 1 to 2-yr flow events in a 9-month period between April and October 2009 resulted in approximately 20 to $30 \mathrm{~m}$ of bank retreat at some sites. A historical flood event of greater than $1000 \mathrm{yr}$ return period in 2011 resulted in much less bank retreat (Daly et al. 2015).

A concern not only exists in regard to sediment load from streambanks, but also nutrient loads from these banks. In a recent study of the Barren Fork Creek watershed, Miller et al. (2014) estimated that approximately $36 \%$ of the streambanks are eroding along the $55-\mathrm{km}$ length of the stream and contributing considerable amounts of both dissolved and total phosphorus to the stream. The streambanks were acting as a legacy source of phosphorus in the watershed. They went on to estimate that riparian protection reduced the sediment and total phosphorus load from streambanks by three to four times compared to banks without riparian protection. Other studies have reported similar numbers for phosphorus loads from streambanks: 7 to $10 \%$ of annual total phosphorus (TP) in Minnesota (Sekely et al. 2002), 14 to 24\% of TP in Denmark (Laubel et al. 2003), 21 to $62 \%$ of annual loads for a Danish stream with cohesive banks (Kronvang et al. 2012). 


\section{Gullies as Contributor to Sediment Load to Reservoirs}

Soil erosion from agricultural land can compose $40 \%$ to $70 \%$ of total sediment load in streams and has been recognized as a major contributor to stream and reservoir sedimentation. Two types of soil erosion usually considered are sheet and rill erosion and gully erosion. Sheet and rill erosion is a process of soil removal and transport from hillslopes to drainage ways in lower parts of a field either by a uniform overland flow or in numerous small channels, or rills, easily obliterated by tillage. Gully erosion occurs in narrow channels along drainage ways where overland water runoff accumulates and gains enough energy to detach and transport sediment. The concentrated flow channels that are too deep to farm with tillage equipment, typically from $0.5 \mathrm{~m}$ to as much as $30 \mathrm{~m}$, are defined by the Soil Science Society of America as permanent (classical) gullies, whereas the "small channels eroded by concentrated flow that can be easily filled by normal tillage, only to reform again in the same location by additional runoff events" are classified as ephemeral gullies (Soil Science Society of America 2008). In most cases as proposed by Hauge (1977), rills can be distinguished from (ephemeral) gullies by a critical crosssectional area smaller than $929 \mathrm{~cm}^{2}\left(1 \mathrm{ft}^{2}\right)$. Erosion is non-uniform along the gully with deeper channel incision at the headcut and wider banks closer to the outlet. As noted by Poesen et al. (2011), "the transition from rill erosion to ephemeral gully erosion to classical gully erosion and to river channel erosion represents a continuum," and any classification based on the rill size is subjective. Cropland fields are more prone to ephemeral gully erosion, while grassland can be severely affected by classical gully erosion.

Formation of ephemeral and classical gullies is affected by many factors, such as overland flow hydraulics, rainfall depth and intensity, topographic features, land use and management, and soil type and lithology, among others. A widely used approach implies that 

exceeds the critical shear stress of soil, which is dependent on soil type and texture, antecedent soil moisture content, vegetation density, plant roots, etc. The frequency and peak of runoff intensities that have been gradually increasing with climate change create more favorable conditions for gully development. Topography plays a major role in gully formation and progression. A combination of factors, such as contributing drainage area, slope gradient, and planform curvature, form a so-called topographic index model that is able to identify the potential ends of a gully channel within a field. This approach is beneficial for tracking fields and locations for gully development as well as calculating potential maximum sediment loads from ephemeral and classical gullies. While substantial progress in the utilization of topographic indices to predict gully locations has been made, the specific influences of soil properties and vegetation represent a current knowledge gap (Momm et al. 2012). Due to intensive legacy tillage operations, ephemeral gullies on cultivated croplands normally have a layer of compacted soil (a hardpan) underneath the topsoil which reduces the soil's capability of draining the infiltrating water and decreases critical soil shear stress. Therefore, better drained soils, more residue on soil surface, and small grain crops tend to increase soil protection from concentrated overland flow, reducing the risk of gully erosion.

Recent studies have shown that ephemeral gully erosion worldwide can contribute from $30 \%$ to as much as $83 \%$ to total soil erosion with annual soil loss as high as $90 \mathrm{Mg} / \mathrm{ha}$ (Foster 1986; Poesen et al. 2011; Daggupati et al. 2014). The Cheney Lake CEAP project in southcentral Kansas concluded that ephemeral gully erosion, the greatest source of sediment in the watershed, accounted for about $0.55 \mathrm{Mg} / \mathrm{ha}$ of soil lost annually (Osmond et al. 2012). In Goose Creek subwatershed, 178 active ephemeral gullies were found with lengths ranging from 30 to 
about 1,000 m. Total gully length was $74 \mathrm{~km}$, averaging $220 \mathrm{~m}$ per 40 ha (about 100 acres) (Douglas-Mankin et al. 2011). More than 55\% of ephemeral gullies were found in low-residue wheat cropland without terraces. A field study by Karimov et al. (2014) estimated that in 2013, $55 \%$ of total soil erosion from a no-till sorghum field was produced by advancement of the gully headcut alone.

Similar to streambanks, gullies can cause a negative impact on nutrient loads, although the research on the quantitative impact is still very limited. Due to stratification, phosphorous, for example, decreases quickly with depth, which makes the phosphorous loss dependent on the depth of origination. Gully erosion affects soil at deeper layers than sheet and rill erosion, which degrades mainly the topsoil. Knowing the ability of sediment to adsorb phosphorus, ephemeral gully erosion can greatly increase the total phosphorous loss while decreasing the dissolved phosphorus loss (Zheng et al. 2005). More studies need to be conducted to assess tillage and management practice effects on gully erosion on nutrient loads.

Most conservation practices that are implemented for erosion control have been deemed beneficial for preventing ephemeral erosion. For the majority of agricultural fields, conservation tillage or no-till combined with terraces and contour farming can sufficiently control gullies. In severe cases, grassed waterways and designed surface water disposal systems are needed. In some fields with the severest channelization, permanent structures that drop water to a lower elevation are required to prevent headcut migration and an ephemeral gully from becoming a classical gully. 


\section{Future Research Needs}

Variability in loading from upland sources can occur for a variety of reasons, including limitations associated with measuring sediment transport. Is variability related specifically to land management or weather and climate? Without a doubt, hydrology and hydraulics drive the erosion and sediment transport processes, but the processes described above are dependent on a number of other factors. Land management and development in watersheds influence the erosive forces of runoff waters that occur on upland agricultural fields and eventually reach our streams and rivers. Continued land use changes and development can drive multiple hydraulic disturbances that influence the formation of gullies and impact stream systems, making the status of the bank within the channel evolution model difficult to assess. Future research is needed on how upstream watershed conditions influence erosion and sediment transport.

\section{Sediment Measurement Research Needs}

Even though sedimentation is depleting water supply reservoir capacity, degrading water quality and negatively impacting aquatic life, sediment concentration remains one of the more poorly quantified water quality parameters. This is primarily due to the difficulty in obtaining accurate estimates of sediment transport. New technologies for measuring suspended-sediment transport include acoustic backscatter, digital-image analysis, LISST laser diffraction, optical sediment flux, and pressure differential and bulk optics (Kuhnle and Wren 2006). Only the LISST series of laser diffraction instruments, acoustic backscatter meters (single frequency and multi-frequency), and several types of bulk-optic meters (optical backscatter, nephelometry, and transmission devices) are available commercially. 

measurements. Bed load measurement techniques can be categorized as instream installations, portable/physical devices, and surrogate technologies. Instream installation methods include Birkbeck samplers, vortex samplers, pit traps, net frame samplers and sediment detention basins. Portable measuring devices include pressure-difference samplers (such as the U.S. BL-84, Helley-Smith, Toutle River, and Elwha River bed load samplers), bed load traps, instream baskets, tracer particles, scour chains and bed load collectors. Although these devices are the mainstays in measuring bed load and have provided useful data in a variety of settings, they all have deficiencies that restrict their use and prevent widespread acceptance as the standard method for monitoring bed load. Surrogate technologies being explored include Acoustic Doppler Current Profilers (ADCPs), hydrophones, gravel impact sensors, magnetic tracers, magnetic sensors, topographic differencing, sonar-measured debris basins and underwater video cameras (Ryan et al. 2006).

Of these, ADCPs show the most promise in the immediate future for both sediment and bed load transport. ADCPs use acoustic transducers operating at megahertz frequencies to transmit sound pulses on the order of microseconds into the water column. As the pulse propagates through the water column, sediments in suspension backscatter a proportion of the sound to the transducer. Because of the Doppler effect, the frequency of the return signal is altered, depending on the relative velocity of the particles to the ADCP. By using multiple beams, the ADCP can determine the magnitude and movement direction of particles suspended in the water column. Further, the backscatter intensity, i.e., the strength of the return signal, is a 
function of the concentration and size of the sediment in suspension, allowing the ADCP to be used as a surrogate method of estimating concentration (Deines 1999; Kim and Voulgaris 2003).

ADCPs have already been accepted for measuring stream flow, and the United States Geological Survey is routinely using them throughout the United States. The Survey has also recently released guidance on the use of ADCPs for measuring stream discharge (Mueller and Wagner 2009). Similar protocols had previously been developed by the Water Survey of Canada (2004), and water agencies across the world are increasingly using ADCPs for measuring stream discharge in their countries. Over the last decade, ADCPs have also been used to estimate suspended sediment concentrations in rivers (Filizola and Guyot 2004; Kostaschuk et al. 2004; Wall et al. 2006) and estuaries (Kim and Voulgaris 2003). These sediment applications show promise and warrant further attention and skill assessment, particularly in a wider variety of streams and gullies.

Several groups have tried to use ADCPs to quantify bed load transport (Rennie et al. 2002; Gaeuman and Jacobson 2007). They exploit the bottom tracking capability of commercially available ADCPs for measurement of bed load velocity with the goal of developing a non-invasive technique for gauging bed load transport. Bottom tracking is used to determine the speed of a boat taking ADCP measurements and involves measuring the Doppler shift in the frequency of an independent echo-sounding off of the bed. If the bed is mobile then bottom tracking is biased by the sediment motion, and the frequency shift is from both the boat speed and the sediment movement so that a stationary boat in the stream would appear to be moving upstream. The USGS “Quality-Assurance Plan for Discharge Measurements Using Acoustic Doppler Current Profilers" (Oberg et al. 2005) presents two acceptable methods for performing a moving-bed test. One requires that the "ADCP be held in a stationary position 
while recording ADCP data for 10 minutes, using bottom tracking as the boat-velocity reference." If the bed is moving the ADCP will appear to have moved upstream. This "error" is in fact the bed load velocity, which theoretically could allow the ADCP to indirectly measure bed load. As with the sediment measurements, these methods for bed load show promise, but they warrant further attention and skill assessment, particularly in the wide variety of streams.

\section{Streambank Research Needs}

For streambanks with the same climate and upstream land management and use, differences in the current bank status in regard to the channel evolution model, the bank structure (soil texture, bulk density, fluvial erodibility properties and geotechnical properties), and bank composition (layering, presence/absence of riparian vegetation) cause variable contributions of sediment from streambanks within the same watershed and between watersheds. Streambanks separated by only a few stream miles on the same stream or river can have drastically different erodibility characteristics (see an example in Figure 2 from Heeren et al. 2012). It is imperative that before we invest funds for streambank restoration/streambank rehabilitation that we understand the current condition and longitudinal variation in properties of the bank relative to its watershed hydrology and potential future watershed development through indicators such as the channel evolution model. Future research should also be devoted to clarifying the benefit of restoration or stabilization of a small-reach within a channel system on total watershed sediment load. What is the actual benefit of an isolated restoration or stabilization project on a stream compared to other significant sources of sediment and relative to both upstream and downstream erosion and instability? 
When stabilization and restoration are attempted, practitioners have limited information and rarely measure the erodibility of bank sediment, rather relying on qualitative metrics or classification schemes to predict erodibility. In-situ methods are available for quantifying erodibility characteristics using the Jet Erosion Test (JET), as described by Hanson (1990), Hanson and Simon (2001), and Al-Madhhachi et al. (2013), and geotechnical characteristics using borehole shear tests (BSTs). While general trends are typically observed between erodibility and more easily measured soil properties, such as soil texture (clay, silt, and sand content), recent research points to the need to measure these properties in-situ rather than attempting to use empirical relationships (Daly et al. 2013). More research is needed on standardized methods for conducting JETs, BSTs, and the derivation of fluvial erodibility and geotechnical parameters. Furthermore, fluvial erosion for cohesive sediment is still largely predicted in process-based models using a linear excess shear stress approach developed by Parthenides (1965). The field needs to move to more process-based, mechanistic detachment models for fluvial erosion. Recent research has proposed such models with parameters that can be derived from JETs (Al-Madhhachi et al. 2014). Finally, erosion and failure of streambanks typically occurs from isolated extreme events where the banks are primed for erosion and mass wasting to occur. We need to better acknowledge the interconnected role of subaerial processes, fluvial erosion, and mass wasting in this episodic process. Research progress needs to be made in utilizing the best available process-based models for stream channel erosion and bank stability (Hargrove et al. 2010). Such progress will require significant effort in understanding the inputs and required processes to be included in such models.

More research is needed to understand the intricate linkage between upland practices and in-stream response. While conservation practices assist in potentially reducing flow volumes and 
magnitudes reaching streams, the effect relative to historical disturbances in the channel may require a significant period of time, especially when streambanks already represent a significant source of the sediment load. This research will provide key information for the site-specific relationship between watershed land cover/land use changes and the time period required for stability (i.e., quasi-equilibrium stage of the channel evolution model) of the stream to be achieved. Also, how do we balance investment in upland versus in-stream conservation and erosion control practices? Determining these relationships and answering such questions will be extremely difficult with statistical or empirical models or even classification-based schemes, and as such will require process-based modeling linking the upland and stream system.

\section{Gully Research Needs}

The landscape on agricultural fields is dynamic and changes in response to soil erosion, especially gully erosion. Ephemeral gullies tend to occur in the same location each year along the drainage pathways and cause the drainage network to gradually become more incised into the landscape. Sheet and rill erosion transports sediment from hillslopes and settles it in these incised channels during runoff events. The washout sediment is composed of larger particle sizes than the topsoil and has poor cohesion properties. As a result, the system waits for the next big runoff event to pick up the channel sediment and transport it further downstream, similar to fluvial systems. Understanding where channel incision and sediment deposition zones occur in the field becomes increasingly important for targeted management practice placement. Modeling of gully erosion processes, prediction of geographical locations of classical and ephemeral gullies, and estimation of erosion rates are crucial for gully research. 
Process-based gully erosion models that are currently available can estimate gully erosion rates, but they require a large amount of input data, are usually applied only at specific sites, and use regression relations that need to be calibrated over a wide range of field conditions. On the other hand, topographic-index models are fairly simple, require a small amount of input data, and can be run for larger areas at once. The availability of high-resolution geospatial datasets, such as LiDAR, field-based land use data, SSURGO soils, etc., can improve the reliability of topographic-index models substantially; however, the accuracy of results will still depend on validation with actual gullies. Thus, improved techniques that efficiently and accurately measure gully morphology are needed in order to provide data suitable for model validation.

We also need a better understanding of intricate interactions between gully erosion processes and hydrological processes to improve prediction, location, and timing of gully formation and upstream progression. As an example, the importance of antecedent soil moisture condition and seepage or piping in gully erosion processes are widely overlooked and should be better addressed in physical models (Wilson et al. 2013). The improved techniques and understanding of physical processes that cause gully erosion will advance the development of effective measures and management practices that currently lack an ability to estimate sediment delivery and reduction rates.

\section{Conclusions}

Reservoirs are critical features for long-term sustainability of water supplies and to provide flood protection. As the demand for water continues to grow due to economic development and population growth, the reliance on reservoirs will continue to accelerate. 
Experts continue to state the need to shift from building new large capacity reservoirs with an assumed life-span whereby the design and operations focus specifically on flow and storage to a focus on extending the life of existing reservoirs through simultaneous management of both water and sediment. Upstream erosion control is critical for extending the life-span of reservoirs, but we must consider all upstream sediment sources, including streambanks and gullies, and continue to improve the measurement of sediment transport. While recent advances have been made over the past two decades in these fields, critical research is still needed for the community to fully understand and predict sediment loading associated with streambanks and gullies and ultimately develop the most cost-effective practices to reduce these loading rates.

\section{Acknowledgements}

The authors acknowledge the Big XII Water Workshop for organizing the authors around the theme of erosion, sediment transport, and reservoir sedimentation, and we thank the support for attending from the respective institutions.

\section{References}

Al-Madhhachi AT, Fox GA, Hanson GJ, Tyagi AK, Bulut R (2014) Mechanistic detachment rate model to predict soil erodibility due to fluvial and seepage forces. J. Hydraul. Engr. 140(5), doi:10.1061/(ASCE)HY.1943-7900.0000836.

Al-Madhhachi AT, Hanson GJ, Fox GA, Tyagi AK, Bulut R (2013) Measuring soil erodibility using a laboratory “mini” JET. Trans. ASABE 56(3): 901-910. 
American Society of Civil Engineers (ASCE) (2008) Sedimentation Engineering: Processes, Measurements, Modeling and Practice. ASCE Manual sand Reports on Engineering Practice No. 110, ed. M.H. Garcia, ASCE, Reston, VA.

Barclay JS (1980) Impact of stream alterations on riparian communities in southcentral Oklahoma. Fish and Wildlife Service Contract 14-16-0008-2039, Fish and Wildlife Service, U.S. Department of the Interior, FWS/OBS-80/17.

Daggupati P, Sheshukov AY, Douglas-Mankin KR (2014) Evaluating ephemeral gullies with a process-based topographic index model. Catena 113: 177-186.

Daly ER, Fox GA, Al-Madhhachi AT, Miller RB (2013) A scour depth approach for deriving erodibility parameters from Jet Erosion Tests. Trans. ASABE 56(6): 1343-1351.

Daly ER, Miller RB, Fox GA (2015) Modeling streambank erosion and failure along protected and unprotected composite streambanks. Adv. Water Res. (in press), doi: 10.1016/j.advwatres.2015.01.004.

Deines KL (1999) Backscatter estimation using broadband acoustic Doppler current profilers. Proceedings IEEE 6th Working Conference on Current Measurements, 249-253, San Diego, CA.

Douglas-Mankin KR, Daggupati P, Sheshukov AY, Barnes P, Devlin D, Nelson N (2011) Cheney Lake Watershed: Erosion from ephemeral gullies. Publication MF-3030. Kansas State University, Manhattan, KS.

Dutnell R (2000) Development of bankfull discharge and channel geometry relationships for natural channel design in Oklahoma using a fluvial geomorphic approach. Master's Thesis, University of Oklahoma, Norman, OK. 
Evans DJ, Gibson CE, Rossell RS (2006) Sediment loads and sources in heavily modified Irish catchments: A move towards informed management strategies. Geomorphology 79: 93113.

Filizola N, Guyot JL (2004) The use of Doppler technology for suspended sediment discharge determinations in the River Amazon. Hydrological Sciences Journal 49(1): 143-153.

Foster GR (1986) Understanding ephemeral gully erosion. In: Soil Conservation: Assessing the Natural Resource Inventory, Volume 2. National Academy of Science, Washington, DC: $90-128$.

Fox GA, Wilson GV (2010) The role of subsurface flow in hillslope and streambank erosion: A review. Soil Sci. Soc. Am. J. 74(3): 717-733.

Gaeuman D, Jacobson RB (2007) Field assessment of alternative bed-load transport estimators. Journal of Hydraulic Engineering 133(12): 1319-1328, doi: 10.1061/(ASCE)07339429(2007)133:12(1319).

Garbrecht J (2007) Climate variations, soil conservation, and reservoir sedimentation. $2^{\text {nd }}$ Joint Federal Interagency Conference, Las Vegas, NV, 7 pages.

Hanson GJ (1990) Surface erodibility of earthen channels at high stresses: II. Developing an in situ testing device. Trans. ASAE 33(1): 132-137.

Hanson GJ, Caldwell L, Lobrecht M, McCook D, Hunt SL, Temple D (2007) A look at the engineering challenges of the USDA Small Watershed Program. T. ASABE 50(5): 16771682.

Hanson GJ, Simon A (2001) Erodibility of cohesive streambeds in the loess area of the midwestern USA. Hydrol. Proc. 15: 23-28. 
Hargrove WL, Johnson D, Snethen D, Middendorf J (2010) From dust bowl to mud bowl: Sedimentation, conservation measures, and the future of reservoirs. J. Soil and Water Conserv. 65(1): 14A-17A.

Hauge C (1977) Soil erosion definitions. California Geology 30: 202-203.

Heeren DM, Mittelstet AR, Fox GA, Storm DE, Al-Madhhachi A-S, Midgley TL, Stringer AF, Stunkel KB, Tejral RB (2012) Using rapid geomorphic assessments to assess streambank stability in Oklahoma Ozark streams. Trans. ASABE 55(3): 957-968.

Juracek KE (2014) The aging of America's reservoirs: In-reservoir and downstream physical changes and habitat implications. J. Am. Water Res. Assoc. 51(1): 168-184, doi: 10.1111/jawr.12238.

Karimov V, Sheshukov AY, Barnes P (2014) Impact of Precipitation and Runoff on Ephemeral Gully Development in Cultivated Croplands. In: Sediment Dynamics: From the Summit to the Sea, Edited by Y. Jun Xu. IAHS Publ. 367. IAHS Press, UK: 87-92.

Kim YH, Voulgaris G (2003) Estimation of suspended sediment concentration in estuarine environments using acoustic backscatter from an ADCP. In Proceedings of the Fifth International Conference on Coastal Sediments, 10 pages, Clearwater Beach, FL.

Kostaschuk R, Best J, Villard P, Peakall J, Franklin M (2004) Measuring flow velocity and sediment transport with an acoustic Doppler current profiler. Geomorphology 68: 25-37.

Kronvang B, Audet J, Baattrup-Pedersen A, Jensen HS, Larsen SE (2012) Phosphorus loads to surface water from bank erosion in a Danish lowland river basin. J. Environ. Qual. 41: 304-313. 
Kuhnle RA, Wren DG (2006) Suspended-sediment measurement: Data needs, uncertainty, and new technologies. Proceedings of the Eighth Federal Interagency Sedimentation Conference, Reno, NV.

Laubel A, Kronvang B, Hald AB, Jensen C (2003) Hydromorphological and biological factors influencing sediment and phosphorus loss via bank erosion in small lowland rural streams in Denmark. Hydrol. Proc. 17(17): 3443-3463.

Lovern SB, Fox GA (2012) The streambank research facility at Oklahoma State University. Resource 19(2): SP10-SP11.

McIntyre SC (2007) Reservoir sedimentation rates linked to long-term changes in agricultural land use. J. Am. Water Res. Assoc. 29(3): 487-495, doi: 10.1111/j.17521688.1993.tb03226.x.

Midgley TL, Fox GA, Heeren DM (2012) Evaluation of the Bank Stability and Toe Erosion Model (BSTEM) for predicting lateral streambank retreat on composite streambanks. Geomorphology 145-146: 107-114, doi:10.1016/j.geomorph.2011.12.044.

Midgley TL, Fox GA, Wilson GV, Heeren DM, Langendoen EJ, Simon A (2013) Streambank erosion and instability induced by seepage: In-situ injection experiments. J. Hydrol. Engr. 18(10): 1200-1210, doi: 10.1061/(ASCE)HE.1943-5584.0000685.

Miller RB, Fox GA, Penn C, Wilson S, Parnell A, Purvis RA, Criswell K (2014) Estimating sediment and phosphorus loads from streambanks with and without riparian protection. Ag. Ecosyst. Environ. 189: 70-81, doi: 10.1016/j.agee.2014.03.016.

Momm HG, Bingner RL, Wells RR, Wilcox D (2012) AGNPS GIS-based tool for watershedscale identification and mapping of cropland potential ephemeral gullies. Applied Engineering in Agriculture 28(1): 17-29. 
Morris GL, Fan J (2010) Reservoir Sedimentation Handbook. McGraw-Hill, New York, NY.

Mueller DS, Wagner CR (2009) Measuring discharge with acoustic Doppler current profilers from a moving boat. U.S. Geological Survey Techniques and Methods 3A-22, 72 pages, Reston, VA (available online at http://pubs.water.usgs.gov/tm3a22).

Podolak CJP, Doyle MW (2015) Reservoir sedimentation and storage capacity in the United States: Management needs for the $21^{\text {st }}$ century. J. Hydraulic Engr.-ASCE, doi: 10.1061/(ASCE)HY.1943-7900.0000999.

Oberg KA, Morlock SE, Caldwell WS (2005) Quality-assurance plan for discharge measurements using acoustic doppler current profilers. Scientific Investigations Report 2005-5183, U.S. Geological Survey, Reston, VA.

Osmond DL, Nelson N, Douglas-Mankin K, Langemeier M, et al. (2012) Ch. 14 - Cheney Lake Watershed, Kansas: National Institute of Food and Agriculture-Conservation Effects Assessment Project. In: How to Build Better Agricultural Conservation Programs to Protect Water Quality: The National Institute of Food and Agriculture-Conservation Effects Assessment Project Experience. Edited by D.L. Osmond et al., Soil and Water Conservation Society: Ankeny, IA, pp. 246-264.

Partheniades E (1965) Erosion and deposition of cohesive soils. J. Hydraul. Div. ASCE 91(1): 105-139.

Poesen J, Torri D, Vanwalleghem T (2011) Ch. 19 - Gully erosion: Procedures to adopt when modelling soil erosion in landscapes affected by gullying. In: Morgan, R.P.C., Nearing, M.A. (Eds.), Handbook of Erosion Modelling. Blackwell-Wiley, Oxford, UK: 360-386.

Rennie CD, Millar RG, Church MA (2002) Measurement of bed load velocity using an acoustic Doppler current profiler. Journal of Hydraulic Engineering 128(5): 473-483. 
Ryan SE, Blunte K, Potyondy JP (2006) Bed load transport measurement: Data needs, uncertainty, and new technologies. Proceedings of the Eighth Federal Interagency Sedimentation Conference, Reno, NV.

Sekely AC, Mulla DJ, Bauer DW (2002) Streambank slumping and its contribution to the Phosphorus and suspended sediment loads of the Blue Earth River, Minnesota. J. Soil Water Conserv. 57(5): 243-250.

Simon A, Darby SE (1999) The nature and significance of incised river channels, In Incised River Channels, 3-18. S.E. Darby and A. Simon, eds. Chichester, UK: John Wiley and Sons.

Simon A, Klimentz L (2008) Relative magnitudes and sources of sediment in benchmark watersheds of the Conservation Effects Assessment Project. J. Soil Water Conserv. 63(6): 504-522.

Simon A, Rinaldi M (2006) Disturbance, stream incision, and channel evolution: The roles of excess transport capacity and boundary materials in controlling channel response. Geomorphology 79: 361-383.

Soil Science Society of America (2008) Glossary of Soil Science Terms. Soil Science Society of America, Madison, WI. Available at https://www.soils.org/publications/soilsglossary/536

Tomer MD, Locke MA (2011) The challenge of documenting water quality benefits of conservation practices: a review of USDA-ARS's conservation effects assessment project watershed studies. Water Sci. Tech. 64(1): 300-310.

Trimble SW (2009) An overview of watershed and reservoir processes. Paper presented at the Soil and Water Conservation Society from Dust Bowl to Mud Bowl: Sedimentation, 

quantitative and semi-qualitative analysis using reservoir sedimentation rates. Geomorphology 50(4): 327-348.

Wall GR, Nystrom EA, Litten S (2006) Use of an ADCP to compute suspended-sediment discharge in the tidal Hudson River, New York. U.S. Geological Survey Scientific Investigations Report 2006-5055, 16 pages, U.S. Geological Survey: Reston, VA. Water Survey of Canada (2004) Procedures for Conducting ADCP Discharge Measurements. $1^{\text {st }}$ Edition, Meteorological Service of Canada, Environment Canada, Ottawa, Canada.

WCD (2000) Dams and development: A new framework for decision making. Report of the World Commission on Dams. Earthscan Publications, London, UK.

Wilson CG, Kuhnle RA, Bosch DD, Steiner JL, Starks PJ, Tomer MD, Wilson GV (2008) Quantifying relative contributions from sediment sources in Conservation Effects Assessment Project watersheds. J. Soil Water Conserv. 63(6): 523-531.

Wilson GV, Nieber JL, Sidle RC, Fox GA (2013) Internal erosion during soil pipeflow: State of the science for experimental and numerical analysis. Trans. ASABE 56(2): 465-478.

Zheng FL, He XB, Gao XT, Zhang C, Tang KL (2005) Effects of Erosion Patterns on Nutrient Loss Following Deforestation on the Loess Plateau of China. Agriculture Ecosystems \& Environment 108: 85-97. 

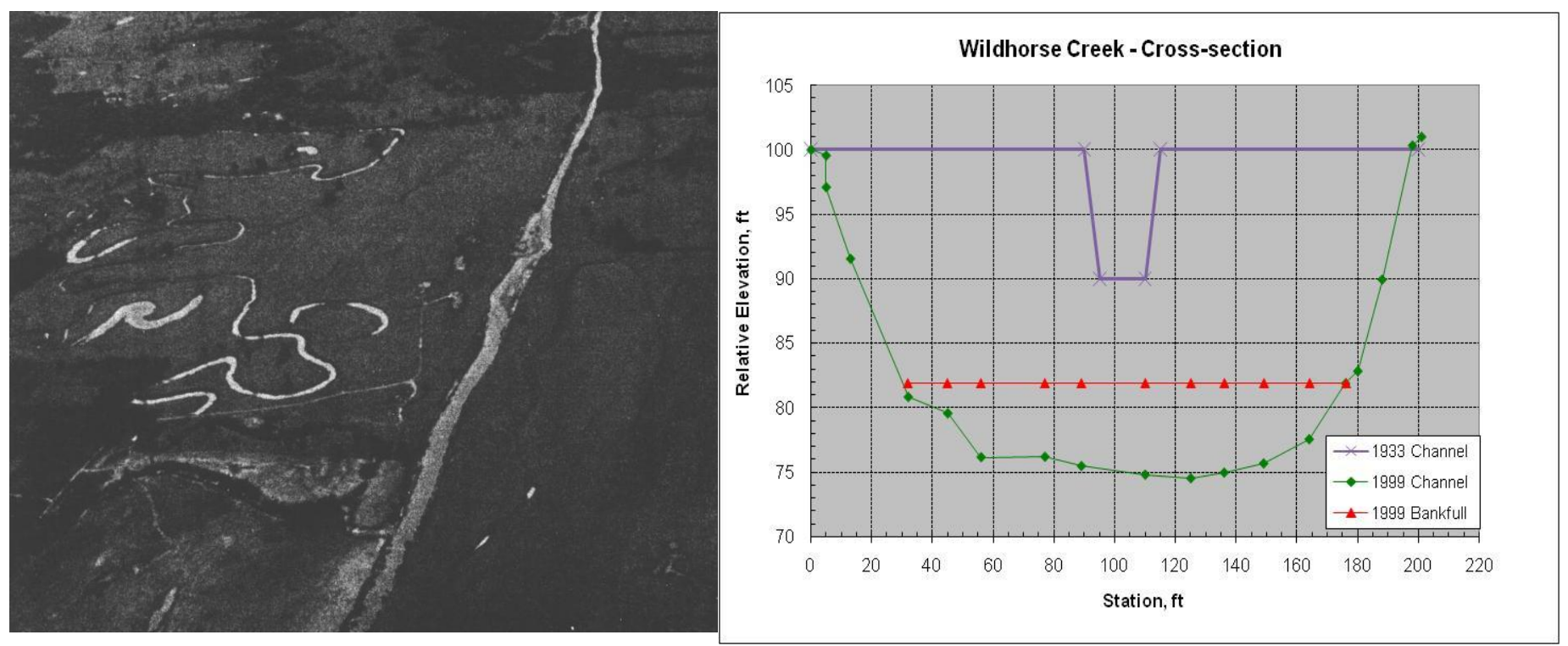

Figure 1. Channelized versus natural meandering Wildhorse Creek channel, in Garvin County, Oklahoma (right, from Barclay, 3 1980); and comparison of Wildhorse Creek channel dimensions (right) in 1933 (blue line - Barclay, 1980) and 1999 (green line Dutnell, 2000). 

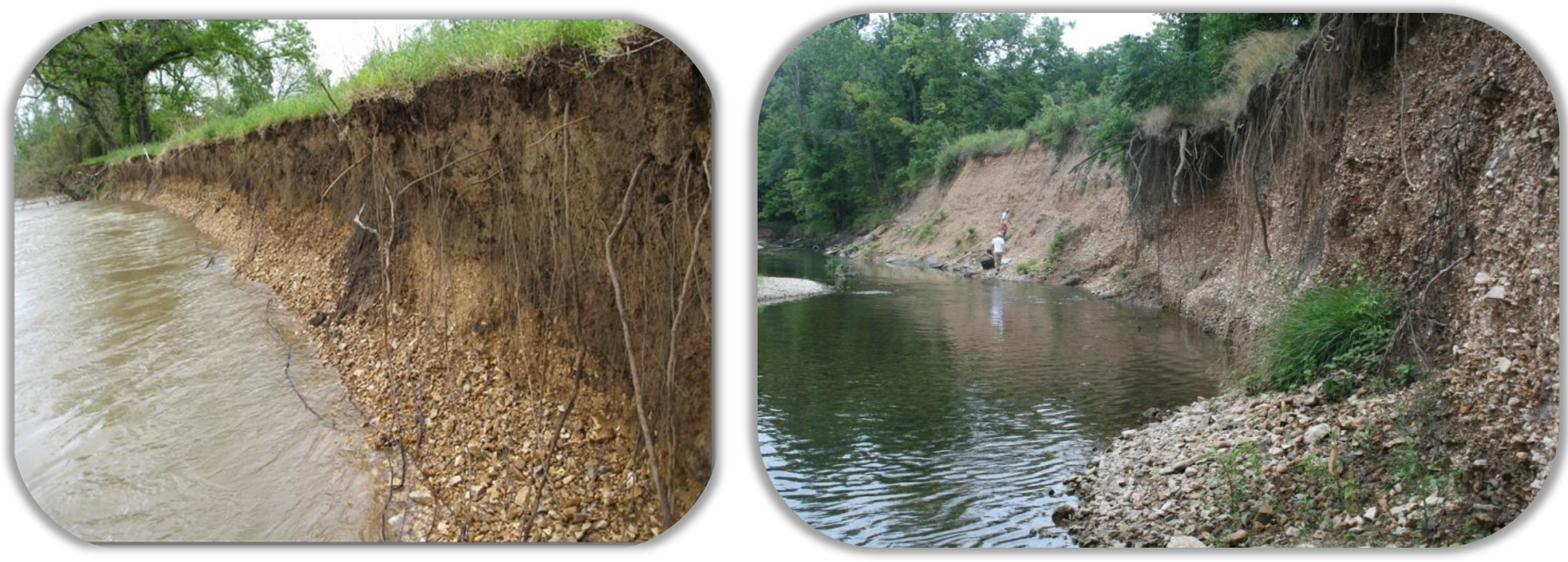

events in 2003-2010). 